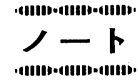

\title{
一方向性炭素繊維／炭素複合材の 圧縮強度の改善
}

\author{
小島 昭* ${ }^{*}$ 大谷杉 郎 ${ }^{* *}$
}

(昭和 58 年 8 月 29 日受理)

\section{Improvement of Compressive Strength of Unidirectional Carbon Fiber Reinforced Carbon}

\author{
Akira Kojima* and Sugio Ōtani** \\ * Gunma Technical College; Toriba-cho, Maebashi-shi 371 Japan \\ ** Faculty of Technology, Gunma University; Tenjin-cho, Kiryu-shi 376 Japan
}

\section{1. 緒言}

著者らはこれまでに, 表面に微細なラーメン構造をむ つ炭素人工歯根材 (FRP インプラント)の試作を行なっ てきだ）。このうち歯根型FRSインプラント用の芯材 としては, 直径 $2 \mathrm{~mm}$ の UD-CFRC (一方向性一炭素繊 維 / 炭素複合材) 棒を用いてきた。乙のCFRC棒は, 高 い曲げ強度 $(1030 \mathrm{MPa})$ で, 人骨之同程度の弾性率 (12 $\mathrm{GPa})$ を示し，歯根材の要求する特性を満足していたが， 圧縮強度は $60 \mathrm{MPa}$ と歯根材が必要とする強度 $(100 \mathrm{MPa})$ には不足していた ${ }^{2)}$ 。圧縮強度以外の問題点として, UD-CFRCは異方性が大であるため, 層間剥離が生じ やすいととやねじれに対して弱い点である。そてで，て れらの点を解決するためにCF (炭素繊維)の配列方法を 一方向から三方向に近づけるととを検討し，下記に示す ような三種類の方法で $\mathrm{CFRC}$ 棒の製造を試みたので，そ の結果について報告する。

\section{2. 予備的検討}

\section{1 くみひもを用いるCFRC 棒の製造}

$\mathrm{CF}$ (PAN, 3000 フィラメント)を12〜16 本程使用し, 直径 2 3 mmのくみひも(四津組，八津組）を製作した ${ }^{3,4}$ 。 このくみひも中にフェノール樹脂を含浸し風乾した後, $150^{\circ} \mathrm{C}$ に加熱してある金型中で成型 $(30 \mathrm{MPa})$ ，硬化し， 直径 $2 \mathrm{~mm}$ あるいは $3 \mathrm{~mm}$ のCERP (炭素繊維/樹脂複合 材) 棒を作った。金型は金属に半円形(直径 $2 \mathrm{~mm}$ あるい は $3 \mathrm{~mm}$ )の溝を掘ったものを上下二枚あわせたものを用

\footnotetext{
*群馬工業高等専門学校工業化学科： $\overline{\mathbf{T}} 371$ 前橋市鳥 羽町 580

** 群馬大学工学部合成化学科 : $\bar{\top} 376$ 桐生市天神町 $1-5$
}

いた。CFRP棒を横型管状炉中にいれ，室素ガスを流し ながら $20^{\circ} \mathrm{C} / \mathrm{hr}$ の速度で $1000^{\circ} \mathrm{C}$ まで加熱して炭素化し CFRCとした。さらに, フェノール樹脂含浸/炭素化の サイクルを二回繰りかえしてCFRC棒をえた。えられた 試料の表面には，CFにそって大きな亀裂がみられた。 また, 柔軟性が残っていたりして, 機械的強度の測定が できないほど弱いCFRC棒であった。従ってCF製くみ ひもを用い，フェノール樹脂をバインダーとして機械的 強度の高いCFRC棒を作ることは困難と考えられた。

\section{2 フィラメントワインディング法による}

\section{CFRC 棒の製造}

フェノール樹脂をバインダーとし, 既報 ${ }^{2)}$ の方法で作 った直径 $2 \mathrm{~mm}$ のUD-CFRP棒およびUD-CFRC棒に, あらかじめCFにバインダーを塗布してあるCF (PAN, 1000 フィラメント)を, CF の配列方向に対し左右ほぼ $45^{\circ}$ ずつ各二層交互につよく手で巻きつけた。そして, これらの試料をフェノール樹脂メタノール溶液中に浸漬 しCF 間の空隙に含浸した後, 風乾し前項 2.1 と同じ 150 ${ }^{\circ} \mathrm{C}$ 亿加熱してある金型中にいれて加圧・硬化し, 直径 3 $\mathrm{mm}$ のフィラメントワィンディングした CFRP (FWCFRP) 棒をえた。これを前項と同様に炭素化し，さら 亿緻密化・炭素化処理を行ない二種類の FW-CFRC 棒 を製造した。その結果，CFRP棒にCFを巻きつけた場 合は, 炭素化時における収縮率が芯棒と外層 $(\mathrm{FW}$ 層)で は異なっているために, 両者の間ではがれてしまい芯棒

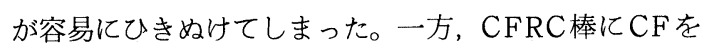
フィラメントワインディングした場合には，そのような 問題点はなかった。しかし, 試料の表面上にはCFの疎 密に伴う凹凸や, 多数の亀裂があった。この FW-CFRC 棒の圧縮強度を求めたとてろ, $150 \mathrm{MPa}$ と高くなってい 
たが曲げ強度は $120 \mathrm{MPa}$ と低下していた。フィラメント ワインディング法はCFRPの製造には有効な手法であ るが，樹脂の炭素化収率が低いために機械的強度の高い CFRCを製造する場合には試料の表面上に深い亀裂が発 生し不適当であった。乙れらの予備的な検討結果から一 方向性の芯に, フィラメントワィンディング法よりは粗 密の差が小さく，総体的には均質で明確な亀裂の入りに くいと思われるCFペーパー層を形成させるととを検討 した。

\section{CF ペーパー積層によるCFRC 棒の製造}

前 2 項の予備的検討の結果, 黒鉛微粉末を含むフェノ 一ル樹脂を CF (PAN， 3000 フィラメント， $2500^{\circ} \mathrm{C}$ 熱 処理物)に塗布し， $80^{\circ} \mathrm{C}$ 亿加熱してある前項と同じ金型 中にてのCFを12本一方向に並べて，予備成型し直径約 $2 \mathrm{~mm}$ の棒状プリホームを作った ${ }^{2)}$ 。次に,フェノール 樹脂がすでに塗布してあるCFペーパー(トレカマット， $\mathrm{BO}-030$, 厚さ $0.2 \mathrm{~mm}$, 目付 $\left.30 \mathrm{~g} / \mathrm{m}^{2}\right)$ を, このプリホ 一ムに2〜3 層まきつけ， $150^{\circ} \mathrm{C}$ 亿加熱してある別の金型 中にいれ, 加圧 $(30 \mathrm{MPa})$ 成形し, 直径 $3 \mathrm{~mm}$ のCFRP 棒を作製した。乙れを前項の場合と同じように緻密化処 理を行ない， $1000^{\circ} \mathrm{C}$ で炭素化してCFRC (S-CFRC) 棒をえた。乙のS-CFRC棒のかさ比重，種々の機械的 強度および曲げ強度測定時の応力一歪曲線を Table 1 に示した。また，CFペーパーをまきつけてない直径 2 $\mathrm{mm}$ の UD-CFRC 棒の場合む表中に併せて記した。SCFRC棒の方が，UD-CFRC棒の場合よりあかさ比重, 曲げ強度および曲げ弾性率は低いが，圧縮強度は 100 $\mathrm{MPa}$ と高くなった。曲げ荷重を加えた場合の破壊の様 子は，最初に外側の CFペーパー層にクラックが入り， 次に内側のUD材の部分に破壊が抢てり既報 ${ }^{2)}$ の場合之

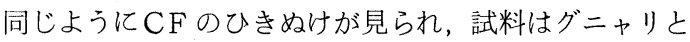
折れ曲っていた。その際の応力一歪曲線は複雑な形状で,

Table 1 Mechanical properties and stress-strain curve with a carbon fiber paper wound CFRC (S-CFRC) rod and a unidirectional CFRC rod.

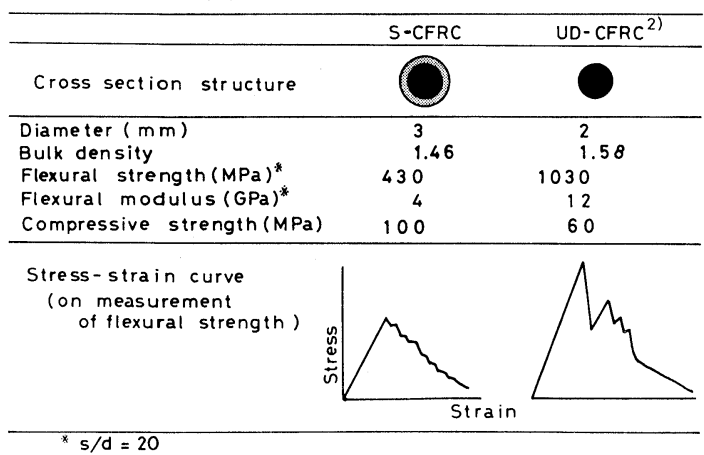

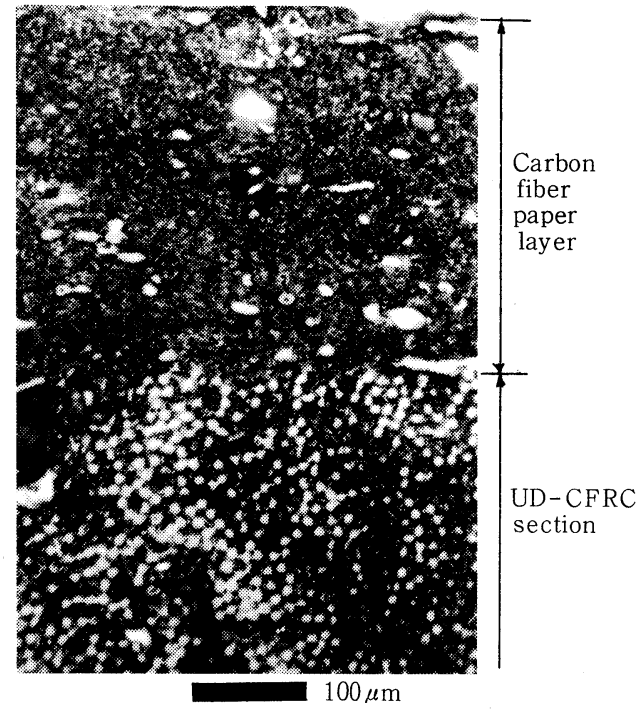

Fig. 1 Cross section structure of a carbon fiber paper wound CFRC (S-CFRC) rod by an optical polarized microscope.

典型的な塑性変形の様子を示していた。次に，S-CFRC 棒の断面の偏光顕微鏡写真を Fig. 1 亿示した。外側の厚 さ約 $300 \mu \mathrm{m} の \mathrm{CF}$ ペーパー層と, 内側のUD材部之が全 く一体化していた。しかし，ての上うに良好な断面構造 をむつS-CFRC棒を作る場合に，充分注意しなければ

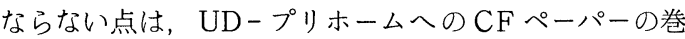
きつけ方である。乙の点がうまくゆかないと，CFペー パー層とUD材との間にクラックが生じたり，あるいは

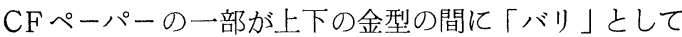
はみ出して取りのぞかれ，連続した $\mathrm{CF}$ ペーパー層でな くなるために，強度の高いCFRC 棒を製造することはで きなかった。

UDープリホームの外側にCFペーパーをまきつける ことにより，三次元的配列をむった一種の擬似等方性 CFRC棒が製造され，UD-CFRCの場合よりも圧縮強 度を高めることができた。

終りに，組みひもを製作してくれた群馬大学工学部井 田ちえみ嬢に感謝します。

\section{文献}

1) Akira Kojima, Sugio Ōtani, Sadakatsu Yanagisawa, Kunio Niijima, and Terushi Iwata, Carbon, in press.

2）大谷杉郎，小島 昭，飯塚重雄，星野新吾，神津正 史, 炭素 1983 (No. 113) 53.

3）広沢徳三郎監修，岡村加代「組みひも」p.1，主婦 之生活社

4) 山本 董「くみひもの研究」p.1 (1978), 総合科学 出版. 